\title{
Impact of Digitalization on Traditional Banking
}

\author{
Uma Raghavendra Gurram ${ }^{1 *}$, Anudeep Velagapudi ${ }^{2}$ \\ ${ }^{1,2}$ Student, Department of Marketing, Universal Business School, Karjat, India \\ *Corresponding author: raghavendra99.com@gmail.com
}

\begin{abstract}
Internet banking is changing the banking business, having the significant impacts on banking connections. Banking is currently not, at this point restricted to the branches where one needs to move toward the branch face to face, to pull back money or store a check or solicitation an announcement of records. In obvious. Internet banking, any request or exchange is prepared online with no reference to the branch (anyplace banking) whenever. The net banking, in this way, presently is to a greater extent a standard instead of an exemption in many created nations because of the way that it is the least expensive method of giving banking administrations. This examination paper will acquaint you with e-banking, giving the significance, capacities, types, focal points, and impediments of e-banking. It will likewise show the effect of e-banking on conventional administrations lastly the outcome documentation. Digitalization diminishes human mistake and hence assembles client reliability. clock admittance to banks because of web based banking. Clients need not store money any longer and can make exchanges at any spot and time. A few business banks began moving towards advanced client administrations to stay serious and important in the race. Banks have profited in a few chime more current innovations. E-banking has brought about lessening costs radically and has produced income through different channels. Business Banks in India have moved towards innovation by method of Bank Mechanization and $n$ to MICR based check preparing, Electronic Funds move, Interconnectivity among bank Branches and usage of ATM (Automated Teller Machine) Channel have brought about the comfort of Anytime banking. Solid activities have been taken by $t$ Reserve Bank of India in fortifying the Payment and Settlement frameworks in banks. Indian government, banks, fintech organizations have been advancing and changing the way India goes through its cash. Simultaneously computerized transformation additionally raises new test the steadiness and the honesty of the budgetary framework and the security of purchasers.
\end{abstract}

Keywords: Banking service, E-Banking, Functions, Internet, Traditional banking.

\section{Introduction}

Banking and Financial Sector has gone through numerous progressions and enhancements over the most recent couple of years and is in a steady condition of improvement. Digitalization has brought the banking business new plans of action, advancement ideas and zones of upgrades, from internet banking to money related exchanges. These New executions to the Financial Sector require the workers just as the clients to know about the quickly changing banking condition and the general condition of progress in the budgetary segment. Presently, digitalization and change the board are one of the significant turbulences that are changing the banking business always and with awful administration, the outcomes can be dependable. During the following many years, banking and budgetary divisions are growing quicker than any time in recent memory and subsequently change the executives and digitalization are at a key situation on the best way to pick up market advantage against equaling banks. In Today's Technology insightful client base, it is significant for Banks to adjust the most recent innovation, to such an extent that banks can find the movement with which client inclinations changes. Adaption of fresher innovation is likewise basic to challenge contender banks and different foundations in offering items and administrations in the commercial center. (Ref. Indian Banking division experiencing significant change). Likewise, with the New period of Digitalization in the banking part, the day by day activities are getting quicker, conservative, and simpler for clients to utilize and in this manner each bank is getting a handle on to modify their own tasks to fit the necessities of a requesting client.

\section{Research Methodology}

\section{A. Research Objectives}

Following are the objectives of the investigation:

- To consider the nature, development, and degree of internet banking and services in the Indian banking part

- To evaluate the effect of internet banking on customers and their conduct.

- To analyze the effect of internet banking on the activities, services and clearing framework in the banking segment.

- Study the ascent of electronic transactions framework in India, e-wallets, and digital banks.

- Future development viewpoints and difficulties in internet banking and services.

\section{B. Research Design}

- Primary and secondary data have been utilized in this examination.

- The investigation was directed during the Covid19 pandemic.

- The primary data was taken through survey and the secondary data was taken from diary articles and related scholastic diaries and other writing. 
- Simple Random sampling has been utilized in this investigation.

\section{Literature Review}

Different researches were done to comprehend and break down the adjustments in banking segment because of digitalization. A portion of the researches done are as per the following.

"Intention to adopt internet banking in an emerging economy: A perspective of Indian youth"- This research paper took a stab at understanding the client's discernment and aim towards internet banking selection in Indian setting. This comprehension was accomplished through consolidating; Theory of arranged conduct (TPB), Technology acknowledgment model (TAM) and an extra build, for example seen hazard. The discoveries of this research demonstrated that apparent convenience, disposition, emotional standard, and saw social control altogether impacts the shopper's aim to receive internet banking while saw hazard don't have any effect on clients over aim to embrace internet banking.

"The Impact of Internet Banking on Bank Performance and Risk: The Indian Experience" - The paper depicts the present status of Internet banking in India and talks about its suggestions for the Indian banking industry. Especially, it looks to inspect the effect of Internet banking on banks' exhibition and danger. The examination done under this exploration tells that Internet banks are bigger banks and have proficiency proportions and productivity when contrasted with non-Internet banks. Web banks depend more vigorously on center stores for subsidizing than non-Internet banks do. Notwithstanding, the various relapse results uncover that the productivity and offering of Internet banking does not have any huge relationship, then again, Internet banking has a huge and negative relationship with hazard profile of the banks.

"A Theoretical Model for Internet Banking: Beyond Perceived Usefulness and Ease of Use"- This Research paper attempted to ask various sorts of electronic banking like ATM's, phone banking, and electronic supports move, Internet banking like has advanced from buyers' needs to have better access than banking services away from most banks teller-staffed, ordinary working hours. Web banking (IB) keeps on overseeing the scene of electronic banking as buyers keep on utilizing IB to finish plan banking exchanges notwithstanding directing online deals and buying. This examination presents a hypothetical model considered to support scientists and professionals better comprehend the acknowledgment and reception of Internet Banking.

"A Study on Factors Influencing Consumer Adoption of Internet Banking in India"- This examination papers attempts to inspect the elements that impact web banking selection. Utilizing PLS, a model is effectively demonstrated, and it is discovered that web banking is affected by its apparent dependability, Perceived convenience, and Perceived value. It says that in the showcasing cycle of web banking services, promoting master ought to accentuate these advantages. Its mindfulness can likewise be improved to stand out for consumers to web banking services.

In 2018, Raghavendra Nayak led an examination to discover issues and difficulties in provincial India after digitalization in banking. Creator in his investigation found that there are various issues in the method of usage of digitalization in rustic India like education, infrastructural issues, less employments of keen telephone by country individuals, banking propensities for provincial individuals, client observation towards innovation based banking.

In 2012, Laila Memdani directed an investigation about outline of digitalization in rustic India and its effect on rustic economy. Being an agrarian nation India is going towards mechanical improvement at an exceptionally quick rate. Creator expressed that advancement in ICTs (Information and correspondence innovation) many Indian little segment organizations are getting a charge out of the advantages. Cisco and BT set up phone-based helpline to give guidance and direction to the rustic ranchers about cultivating. Creator reasoned that however digitalization having bunches of issues also, challenges, rustic individuals are prepared to acknowledge mechanical progression.

\section{Analysis}

Count of Gender

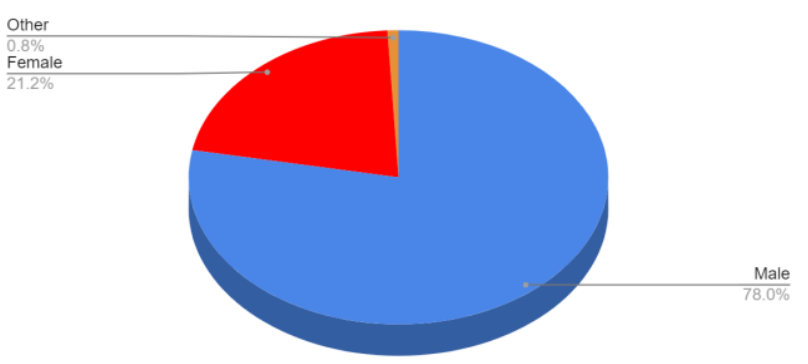

Fig. 1. Count of gender

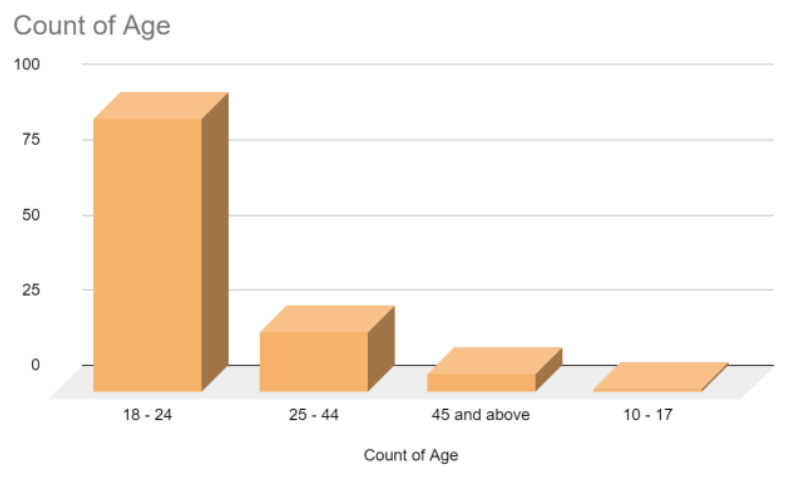

Fig. 2. Count of age 
Count of Occupation

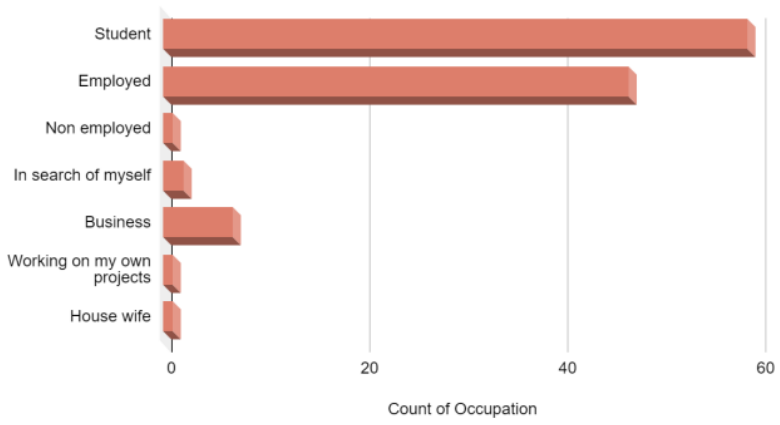

Fig. 3. Count of occupation

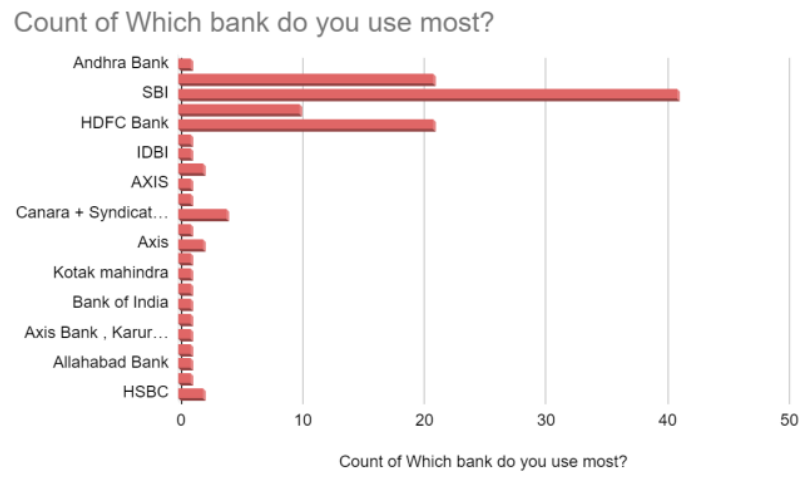

Fig. 4. No. of users for each bank

Count of From how long you are using bank account?

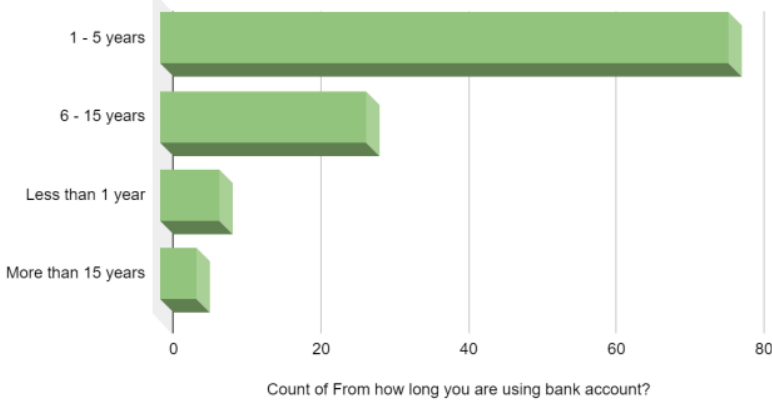

Fig. 5. No. of users with respective period of usage of banking

Count of How often do you visit your bank?

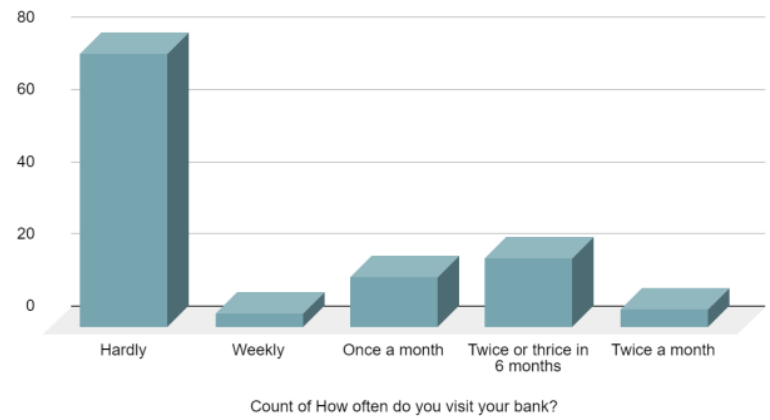

Fig. 6. No. of people and their visits to bank
Count of How much are you familiar with online banking and payments?

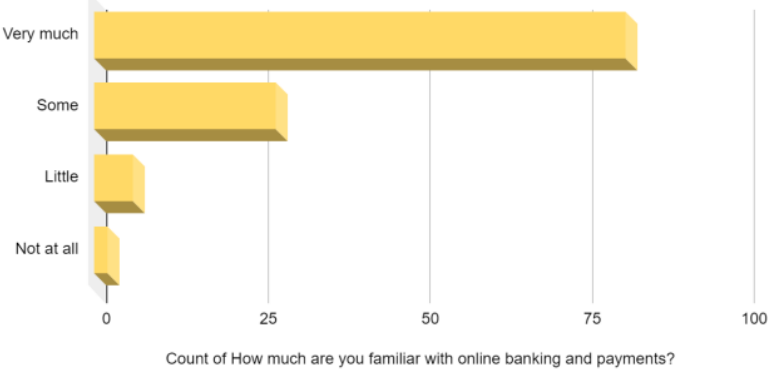

Fig. 7. Familiarity with online banking

Select the following online services you avail.

118 responses

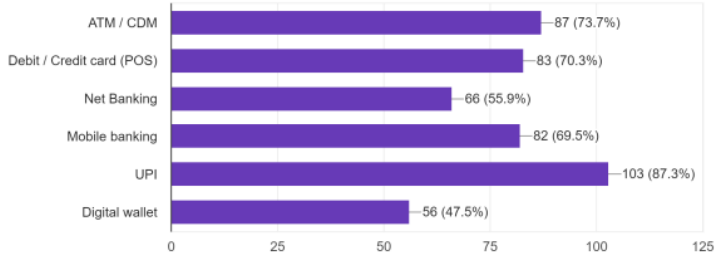

Fig. 8. Count of most used online services

Count of How often do you use the above services?

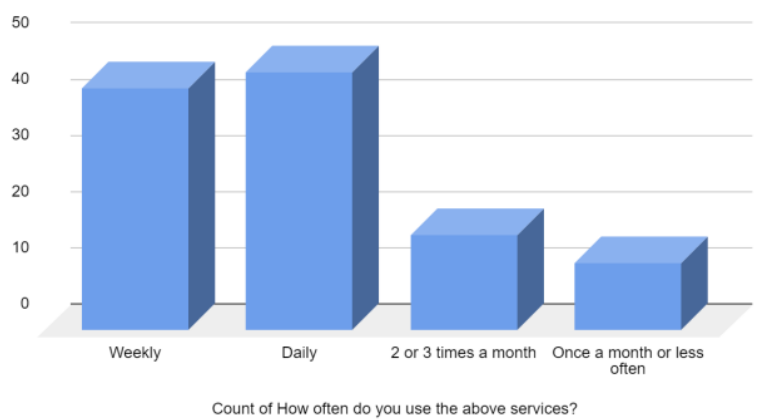

Fig. 9. Usage of online payments

How much percentage of your earnings or expenditure is through online transactions?

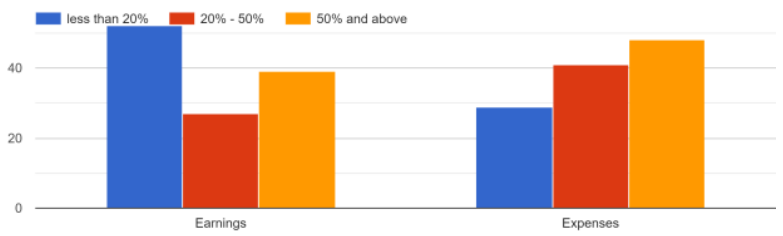

Fig. 10. Percentage of expenses and earnings 


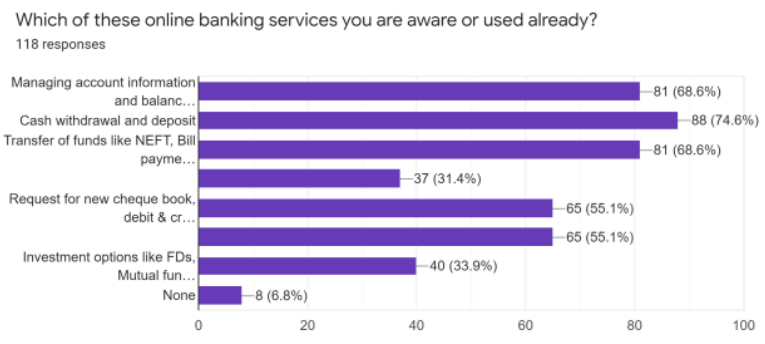

Fig. 11. Awareness of various online banking services

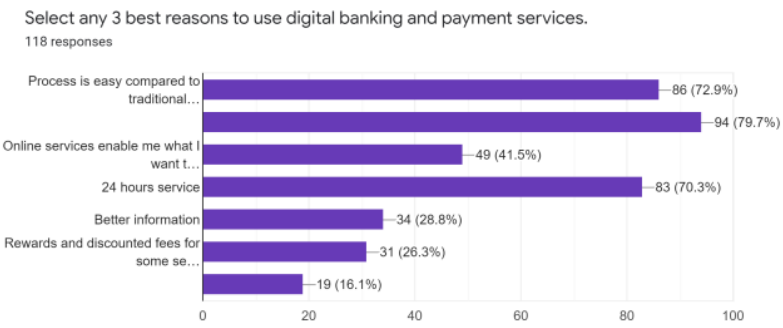

Fig. 12. Reasons to choose online banking

Count of How much are you satisfied with digital services compared to traditional banking?

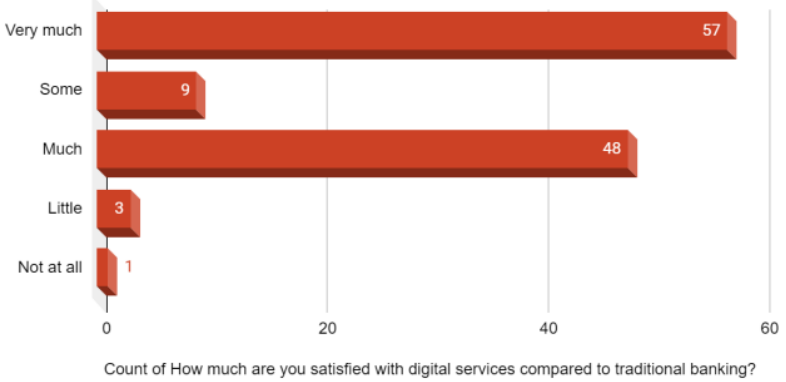

Fig. 13. Satisfaction level of users of online banking services

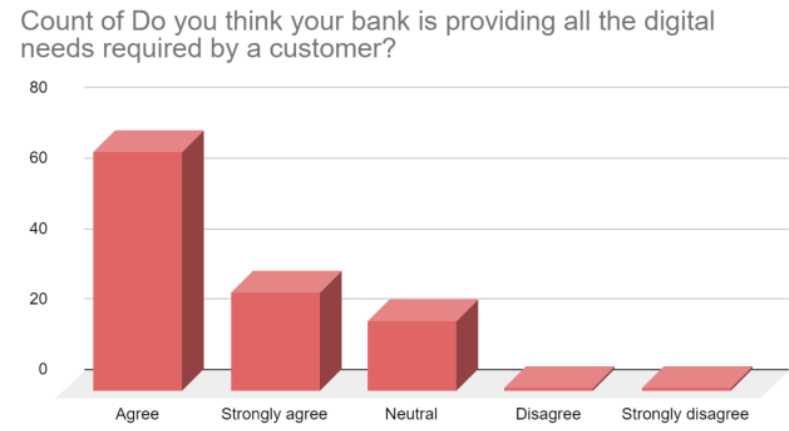

Count of Do you think your bank is providing all the digital needs required by a customer?

Fig. 14. Users agreeableness on banks digital services
Count of Adapting online banking and payment services are

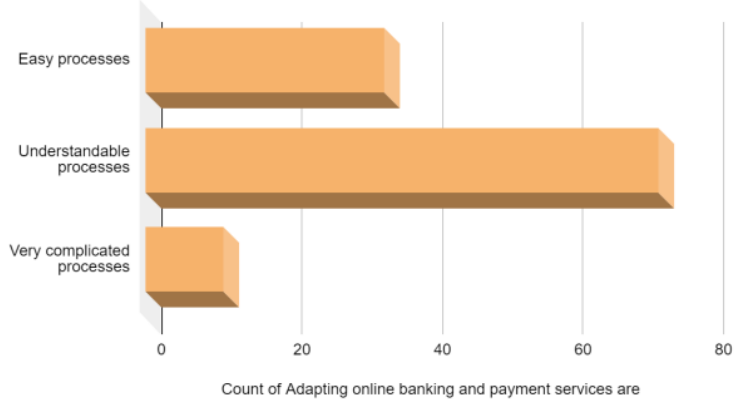

Fig. 15. Users easiness of accessing digital banking services

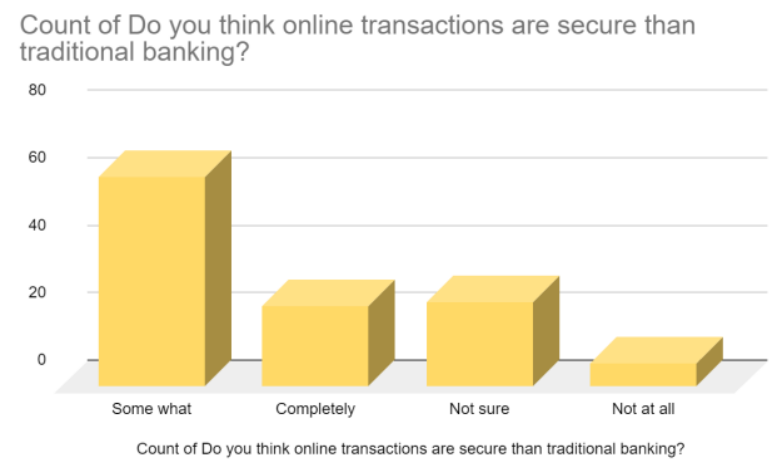

Fig. 16. Users perspective on secureness of digital banking

Count of Will you agree that digital banking is better than traditional banking?

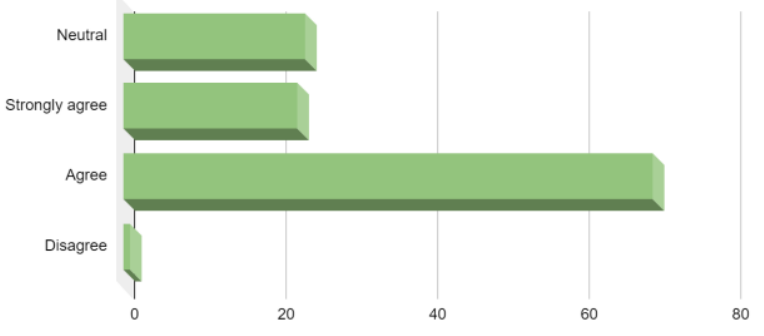

Count of Will you agree that digital banking is better than traditional banking?

17. Count of people whether digital banking is better than traditional banking

\section{Findings and Observations}

- Most of the respondents who are using bank account are not more than 5 years of banking experience. This means most of them started using bank even after digitalization started in India.

- People hardly visits the bank i.e., less than once in a week or neither.

- They are only availing bank account to have one. Not for physical transactions.

- Every one of them are very much familiar with online banking and payments. And the familiarity rate is high. Banks succeed in conveying the importance of digital banking. 
- People are highly availing UPI transactions than the other online payments services. This has more impact on visiting the banks by customers. Followed by card payments, POS, and mobile banking mostly.

- The users are availing online payments services daily. This shows they are doing bank transactions daily but only through online than visiting bank.

- The earnings through online payments are less than $20 \%$ per person mostly. This means earnings are less in most of the bankers through online banking.

- While expenditure for an average user is above $50 \%$ of all their expenses. This shows people more likely to do payments through online transactions.

- Well known digital banking service is Cash deposit and withdrawals followed by account management and funds transfers. These services decreased the users visit to bank.

- The purpose of doing online transactions is it saves time and energy.

- People do not want to waste their time and energy by visiting banks.

- The process is easy in digital banking compared to traditional banking.

- Users want 24/7 banking services whereas normal banking services are time fixed.

- Online services enable what exactly customers want to do.

- Information provided through digital banking is high than normal banking.

- Rewards and discounts on digital payments are enabling users to do online transactions.

- Users do not want to have human interaction shifting themselves to do digital banking.

- Satisfaction level on doing digital banking is much higher than traditional banking.

- The banks are providing all the digital banking services that which is agreed by all the users mostly.

- Users are adapting the digital banking because it is an understandable process.

- Users are neutral in believing the transactions are secure i.e., though they are not sure they are doing digital transactions.

- Over all aspects considered, users agreed that digital banking is better than traditional banking.

\section{Conclusion}

The banking scene is evolving. Another rush of innovation is upsetting the way clients communicate with their funds. From social to versatile abilities, banks are reexamining their method of working together to offer a superior client experience what is more, stay serious. By taking a gander at the situation existing now in India, one can find that People are presently taking increasingly more bit of leeway of the digitalization in the event of banking. As of late, banks are quick to turn out to be more client with the assistance of digitalization Indian banks are currently getting more clients as well as conveying first rate services, as productivity considers well. E-banking is a borderless element allowing whenever, anyplace and at any rate banking. This encourages us with all the capacities and numerous preferences when contrasted with traditional banking services. During this progression of the cycle, controls that could alleviate or dispose of the distinguished dangers, as proper to the organization's tasks, are given. The objective of the prescribed controls is to diminish the level of danger to the IT framework and its data to a satisfactory level.

\section{References}

[1] R. Yadav, V. Chauhan, and G. S. Pathak, "Intention to adopt internet banking in an emerging economy: A perspective of Indian youth," in International Journal of Bank Marketing, vol. 33, no. 4, pp. 530-544, 2015.

[2] P. Malhotra, and B. Singh "The Impact of Internet Banking on Bank Performance and Risk: The Indian Experience," in Eurasian Journal of Business and Economics, vol. 2, no. 4, pp. 43-62, 2009.

[3] S. W. Ezzi, "A Theoretical Model for Internet Banking: Beyond Perceived Usefulness and Ease of Use," in Archives of Business Research, vol. 2, no. 2, pp. 31-46, Apr. 2014

[4] H. M. Rakesh, and T. J. Y. Ramya, "A Study on Factors Influencing Consumer Adoption of Internet Banking in India," in International Journal of Business andGeneral Management, vol. 3, no. 1, pp. 49-56, Jan. 2014.

[5] M. V. Gupta, "The Impact of Digitalisation on Indian Banking Sector," in International Journal of Trend in Scientific Research and Development, p. $5,2018$.

[6] H. Raghuwanshi, "Digital Banking \& Payments," 2018.

[7] R. Nayak, "“A Conceptual Study on Digitalization of Banking - Issues and Challenges in Rural India," in International Journal of Management, IT \& Engineering, vol. 8, pp. 186-191, 2018.

[8] L. Memdan, "An Overview of Digitalization of Rural India and Its Impact on the Rural Economy," in IJBSF, pp. 103-107, 2012. 